\title{
The Primary Source
}

Volume $31 \mid$ Issue 1

Article 6

2012

\section{Hidden Collections at the Georgia Tech Archives}

Jody Lloyd Thompson

Georgia Institute of Technology

Follow this and additional works at: https://aquila.usm.edu/theprimarysource

Part of the Archival Science Commons

\section{Recommended Citation}

Thompson, Jody Lloyd (2012) "Hidden Collections at the Georgia Tech Archives," The Primary Source: Vol. 31 : Iss. 1 , Article 6. DOI: $10.18785 /$ ps.3101.06

Available at: https://aquila.usm.edu/theprimarysource/vol31/iss1/6 


\section{Hidden Collections at the Georgia Tech Archives}

Jody Lloyd Thompson, Head, Archives \& Records Management Department at the Library \& Learning Excellence at the Georgia Institute of Technology

There are a variety of ways an archival collection can be "hidden," such as completely unprocessed or inadequately processed collections, no accession records, improper storage locations or insufficient MARC records just to name a few. The archives at the Georgia Institute of Technology had an unusual "hidden" situation. For years, some of the Institute's key historical documents were unknown to researchers and archivists because the materials were bound.

This treasure trove became known a few years ago when the archivists completed a much-needed inventory. In the history of the Archives, it seems, one had never been done. During the inventory, the archivists noticed very unusual, unique materials inside bound volumes. They were bound historical correspondences located on shelves in the rare book section of the stacks. Most of them seemed to document the early years of Georgia Tech starting in 1885. These bound volumes were the typical black or green plastic binding that you find in most libraries and archives, so it was no wonder they had been over looked for years.

At the Georgia Tech Archives, the collections are typically located on shelves grouped by similar physical formats, such as manuscripts and records, photographs, architectural drawings, and books. The discovery of manuscript materials in the book section was very puzzling and concerning. The archivists had to determine how many other collections would be in the same situation and what other rare Georgia Tech materials would surface. With a small staff (3 archivists at the time, 1 library assistant, and two staff in records management) and 13,000 linear feet of holdings, these just added to the challenges.

Once this oddity was spotted, the archivists conducted a thorough search in the stacks, and they located several other collections including the Board of Trustees (now the Board of Regents of the University System of Georgia) minutes from 1886-two years before Georgia Tech opened. One volume even documented the creation of the Institute. Other unique materials the archivists located were the Faculty Minutes from 1888-1965 that included faculty discussions, decisions, and rulings at Georgia Tech. Also, the Lyman Hall Correspondences were another asset discovered. These volumes were from 1896-1903. Hall was the second Georgia Tech President (1896-1905). The materials consisted of letters to other universities and businesses asking for assistance in expanding Georgia Tech's campus, library, and curriculum. Additionally, commencement and quarter-centennial celebration programs were unearthed, as well as a booklet with photographs and text commemorating the twenty-fifth anniversary of Georgia Tech in 1913.

After thoroughly searching the stacks and uncovering these new collections, the archivists looked into provenance and discovery tools for each of the collections. For most of the materials, provenance was unknown or lacking basic information, such as accession dates, any donor information, and deeds of gifts. To this day, the archivists have no idea when the correspondences arrived in the Archives or why they were bound.

Very limited discovery tools were available for these collections. Some had inadequate MARC records. However, for most of the collections MARC records or finding aids were never created.

Without these basic discovery tools, no one could locate these collections in the Library's catalog 
or on the Archives' finding aid website.

The archivists determined the number of collections that needed to be processed, along with the number of finding aids and MARC records to be created or revised. Overall, there were just a handful of unusual collections; however, the historical value was great. These collections were going to be valuable resources for Georgia Tech students, faculty, and alumni.

After the collections were processed and finding aids created, the next step was to promote the collections. The archivists worked with the Library's IT staff to create a "new collections" page on the Archives' home page. There, the archivists posted brief information about the new collections (One can access the new collections page here:http://www.library.gatech.edu/archives/). Also, an email was sent to the History subject librarian explaining the uniqueness of the situation, and the importance of assisting in the promotion of the materials. The librarian distributed a mass email to all History faculty and graduate students.

The archivists also worked with Georgia Tech's Alumni Association's Living History Program to get the word out about the new collections. It creates oral histories and videos about alums and traditions, and the archives staff has worked closely with them over time. The Archives' relationship with the Alumni Association has proven to be very beneficial for two reasons. One, it gives the Archives access to alums, and second, this connection has brought in many donations of alumni's personal and professional materials to the archives.

Lastly, archivists promoted the collections by introducing them during class orientations and demonstrations. This was an easy way to get the word out. Numerous History and English classes and freshmen orientations classes came to the Archives during the fall and spring semesters. The classes typically had one-hour orientation classes and semester long projects. These previously hidden collections, particularly the Board of Trustees minutes and Faculty minutes, gave the students an understanding of the early years of Georgia Tech, and most importantly, it gave them hands on experience working with primary materials.

The archivists learned several important lessons in the discovery and subsequent remedy of the hidden collections. The first lesson was the value of inventories. Although this process took several months, it showed the archivists all the issues that needed to be resolved, mainly inadequate accession records, too infrequent or missing inventories, and missing collections. If inventories had been completed in the Archives in the past, there was a very good chance that these "hidden" collections would have been discovered years ago. These "hidden" collections would not have been so hidden. Second, discovery tools proved their importance. Without these useful tools, collections would remain hidden; if they exist but are poorly executed, it also allows valuable collections to remain hidden. It seems strange for people who work so closely with collections to be unaware of materials in their own archives due to improper discovery tools! Lastly, because of the desire to promote these collections, the archivists used new and different methods to promote their recently discovered collections on and off the Georgia Tech campus. In the end, these "hidden" collections became true gems in the Georgia Tech Archives' holdings. 